\title{
ペリオと補 綴
}

(医)貴和会歯科診療所 中 村公雄

患者も歯科医も，補緅治療を行う場合，補経物が長持ちすることを期待して治療を行うわけです が, 日常臨床における現状をみると, 補綴物のやりかえがあまりにも多いように思います。一般臨床 医は，歯を削ってかぶせることにあまり抵抗を感じなくなっている傾向にあり，患者も“かぶせたら 安心”という感覚が強いのではないかと思います。しかし，歯を削るということ，そして，そこに充 埧, 補経することの危険性をもっと深刻に考えなければなりません。

補綴治療を避けられるのであるれば可能な限り避けるにこしたことはないでしょう。しかし，いか なる治療においても, 治療結果に永続性が求められることは当然で, 補綴治療を避けたいがために “その場しのぎの治療” となってはならないし，局所的治療にとどめたいがために，短期間の内に破 壊を起こす可能性を残したような “中途半端な治療” となってはならないと思います。補経治療が必 要であると判断すれば，より慎重に補綴治療を行う必要があります。補綴治療を有効な治療のオプ ションにするか破壊の起爆剈にするかは，歯科医師自身の知識と技量にかかってきます。

しかし，一方，いかに精巧な補綴物を作製し得たとしても，その土台となる歯周組織に永続性が期 待できなければ，その補経物の予後は予測しがたいものになることは周知の事実であり，そのため に, 補綴治療を行うに先立って, 歯周組織の適切な治療が必須であることはいうまでもありません。

補綴物作製においては守らなければならない原則がいくつかありますが，やりかえを必要としてい る補綴物は, 補綴治療に際してそれらの原則が守られていなかったように見受けられます。とくに最 近では, 審美歯科の重要性が重視される傾向にあり, 天然歯に似せたポーセレンワークや歯間を鼓形 空隙を開けない補綴物がいかにも優れた補経治療であるかのような意見を散見します。審美は歯科治 療において無視できない一面でありますが，補経治療は結果の永続性が保証されなければ意味があり ません。

補経物が失敗に帰する原因は，歯牙自身の問題と歯周組織の問題，そして補綴物自身の問題があり ますが, 歯周組織との関連において補綴物が長持ちする条件は, 治療後に歯周組織を再度破壊しない 環境づくりであり，そのためには，補綴治療後に清掃しやすい歯周環境をまず整えておくこと，そし て清掃しやすい補綴物の作製が必須ではないかと思います。すなわち，清掃しやすく永続性のある補 綴物の条件としては，以下のごとき事項が挙げられます。

(1) 支台歯周囲が浅いサルカスになっていること

(2) クラウンマージンの位置がサルカス内の浅い部位にあること

(3) 支台歯周囲に付着歯肉が適量存在すること

(4) 補綴物の適合がよいこと

(5) 清掃しやすい形態であること

私どもの診療室においては，補経，歯周治療，矯正，エンド，各々得意とする分野を担当するシス テムを採り，その連携を重視して治療を行っておりますが，特に歯周治療との関わりにおいて上記条 件を考慮して補綴物の永続性をはかるよう努めております。今回その実際を, 症例を通じてお話しさ せていただきたいと思います。 